\title{
Editorial
}

\section{What is music education?}

It might be presumed that a journal which contains the words music education in its title, might have a coherent view as to what its main topic of interest ought to be! But as we have often said in these pages, BJME is a 'broad church', and all sorts of interpretations of the terminology are welcomed. But sometimes, especially for students embarking on academic study of the domain, definitions can be helpful. With this in mind, let us think about what the terminology might mean nowadays.

Estelle Jorgensen (1997, p. 2) offers us two positions to begin our discussion:

First, assuming that Western classical music represents the epitome of musical development and Western music education is the ideal or quintessential form of music education, only Western music and music education are worthy of study. ...

Second, our study broadens to include all forms of music education, irrespective of the societal derivation.

This is interesting, as there are still battles being fought here. These can be characterised as 'music teacher as cultural gatekeeper' matters. But creating this polarity, and asserting only the former, denies a rich living cultural heritage, in which pupils at choir schools play in rock bands, and pupils in inner-city secondary schools sing madrigals. The reality on the ground is far more complex, much more like Jorgensen's second perspective. But in case this is perceived as a dichotomy between child-centred and 'traditional' education, John Finney (2011, p. 2) reminds us that this too needs rethinking:

No longer is a 'child-centred' education promoted. The idea is both passé and politically inept. Instead, there is talk of an education that is 'learner-centred', and where there is 'personalized learning' addressing the needs of the child as a consumer and producer of education.

In the UK, whenever revisions to the National Curriculum for music are proposed, all sorts of anti-revisionists take to the pages of the national press to bemoan the downgrading of Western classical music, in case (perish the thought) children and young people in some schools might actually study music they are interested in! As a former editor of BJME, Stephanie Pitts (2000, p. 34) has observed:

Broadly speaking, music education has been advocated only rarely for the acquisition of subject knowledge, but rather for its desirable cultural influence, its preparation for the profitable use of leisure time, and its development of sensitivity and imagination.

This does create problems for us! But in the nearly 15 years since she wrote this, have things changed? Which brings us back to our main question, what is music education? Hopefully no-one will wish to denigrate the wide variety of activities that take place in 
contemporary schools in favour of a return to some mythical golden-age (which may not have existed)?

In addressing this issue, Wayne Bowman goes back to the bifurcated nature of the word education itself, and considers it from its Latin roots in educare and educere.

... educare, to train or to mold; educere, to lead out or draw out. Educare involves the preservation of knowledge and tradition ... Educere involves preparing new generations for the inevitability of change. (Bowman, 2012, p. 24)

Building on these distinctions, Bowman goes on to say that:

I suggest we call instruction within music 'training' and that we reserve the word 'educating' for musical instruction's broader and more essential life-serving functions.

(Bowman, 2012, p. 32)

These are interesting and useful definitions, which certainly help us on our way a lot. But they also raise an issue for the distinction between 'teaching' and instruction', especially in the UK where historically an instructor has been classed as an unqualified teacher, with instruction concomitantly downgraded to being 'not as good' as teaching. For our transatlantic colleagues, this distinction does not exist to the same extent, but the notion of 'instruction' rather than 'teaching' makes many music educators in the UK bristle somewhat, as the unqualified instructors would be paid less than their teacher equivalents, and have a lower status. But with the rise of direct instruction (DI) as a modality (Engelmann \& Carnine, 1982), maybe this is another terminology due for revision.

But to return to the original discussion, to develop the matter further, it may be helpful to think of three conceptualisations. These are:

(1) Music education

In this usage, music education, the principal focus is with a general education concerning music. It encompasses music generative activities, such as composing and improvising; performing opportunities, and learning about and listening to music.

(2) Musical education

This involves a very specific focus on a small subset of the above, often performing technique, and takes this to be the principal reason for the activity taking place. It can encompass learning at school, in communities or outreach centres; in some jurisdictions this becomes what is meant in totality by 'music education '(thus adding to the confusion). This is certainly what takes place at the conservatoire, and is in many cases delineated by a concentrated focus on developing expertise.

(3) Music in Education

Unlike the first two, this takes as its centre of concern the role that music plays in the general education of learners. It might involve either (or both) of the above, but is conceptually 
separated in that it pays singular attention to the way music functions as a timetabled subject on the school curriculum.

Now, admittedly, these are over-simplistic and crude definitions, with a degree of porousness between them, and they certainly do not hold up to too much by way of definitive analysis, but there is a very real reason for considering them at this time. In the UK, and elsewhere, much attention is being paid to the what of the curriculum in schools. Subjects are jockeying for position, with STEM subjects (Science, Technology, Engineering and Maths) being challenged to include the arts, making the acronym STEAM. Music too falls under this spotlight. We already have the situation where in some jurisdictions a primarily performance modality is how music appears in schools, whilst in others there is a more generalist non-specific approach to music learning. The reason that these distinctions are important is that sometimes one is mistaken for the other! So in the UK we are in the throes of having big arguments, with some holding that music education should not focus solely on learning to play an instrument or singing (what was termed 'musical education', above) but that it should be that which was called 'music education'. This matters because funding follows - or does not follow - and so mistaking one for the other helps no-one. Now, this editorial has not suggested a preference or a hierarchy, the concern has been to observe that the linguistic niceties of the definitions of each can be problematic if not taken into account, especially if all music in education is schools is assumed to follow only one of these paths.

So, what does this tell us? We observed above that the BJME is a 'broad church', and we find a place for articles on all aspects of music education, musical education and music in education in these pages. What matters is when our policy makers, our chief spokespeople, and our leaders and representatives are not clear in their own minds what they are referring to, and so many voices in favour of music education can become diluted by being at odds with each other in the resulting farrago. In an academic journal we need to understand our terminologies, and so we offer these distinctions as a starting point for considering the many roles of music and education.

The first set of papers in the current issue focuses on matters of teaching in higher education, where Gemma Carey and Catherine Grant draw on voices 'from the inside' to reveal teachers' and students' perspectives on one-to-one pedagogy in the context of tertiary vocal and instrumental tuition in an Australian conservatoire. Bringing a Norwegian view, Bjørg Julsrud Bjøntegaard evaluates the merits of alternating between one-to-one pedagogy and small group teaching in order to generate peer feedback, and ultimately to create responsible, reflective and professional musicians. Olle Zandén and Cecilia Ferm Thorgersen trace the challenges for Swedish music teachers as they negotiate a revised curriculum and its attendant assessment methods. Their study describes the dilemmas teachers face when trying to fulfil the demands of the new programme of study while maintaining their own conceptions of quality in music education.

The second set of papers dwells on issues of identity from various perspectives. In a comparative study, Clint Randles and Sari Muhonen seek to validate a measure of creative identity with pre-service teachers in the United States, and then further validate the measure with a population in Finland. They then compare both populations regarding their perceptions of themselves as creative musicians. The differences highlighted between both groups raise questions about creative identity formation in school systems more widely. In Queensland, Australia, Melissa Cain is concerned with the creation of musical 
identities and the crossing of cultural boundaries to embrace music of minority cultures. In particular, she explores the extent to which policies on multiculturalism and music education resonate with teachers' practices in classrooms, ultimately drawing attention to the disjunction between the idealism of policy and the reality of practice in schools. Finally, Patrick K. Freer presents an in-depth analysis of interviews with boys from England, Greece, Ireland and Spain about voice change, school singing and choral music instruction. Issues of identity and loss of identity during voice change are presented, together with issues of gender and sexuality-based bullying. The paper concludes with recommendations for teachers - many arising from the boys themselves - that can support adolescent male singers as they experience change and identity development.

MARTIN FAUTLEY and REGINA MURPHY

BJME Co-Editors

\section{References}

Bowman, W. (2012) Music's place in education. In G. McPherson \& G. Welch (Eds), The Oxford Handbook of Music Education, Vol. 1, p. 21. New York, NY: Oxford University Press.

Engelmann, S. \& Carnine, D. (1982) Theory of Instruction: Principles and Applications. New York, NY: Irvington Publishers.

Finney, J. (2011) Music Education in England, 1950-2010: The Child-Centred Progressive Tradition. Farnham: Ashgate.

Jorgensen, E. R. (1997) In Search of Music Education. Champaign, IL: University of Illinois Press.

Pitts, S. (2000) Reasons to teach music: establishing a place in the contemporary curriculum. British Journal of Music Education, 17, 32-42. 